tucja Biel

Uniwersytet Warszawski

l.biel@uw.du.pl

\title{
EGZAMIN NA TŁUMACZA PRZYSIĘGŁEGO A REALIA WYKONYWANIA ZAWODU: GŁOS KRYTYCZNY W SPRAWIE WERYFIKOWANIA KOMPETENCJI KANDYDATÓW NA TŁUMACZA PRZYSIĘGEEGO
}

DOI: http://dx.doi.org/10.12775/RP.2017.002

\begin{abstract}
Zarys treści: Artykuł jest próbą krytycznej oceny części pisemnej egzaminu w świetle realiów wykonywania zawodu. Ocenie zostaną poddane szczególnie następujące elementy: kryteria oceny, w tym niska waga kryterium zgodności treści oraz brak kryterium błędu krytycznego, zakaz korzystania z materiałów pomocniczych (leksykonów, tekstów ustaw) i ograniczona możliwość korzystania ze słowników, brak dostępu do Internetu oraz konieczność odręcznego pisania podczas egzaminu. Elementy te zostaną skorelowane z modelem EMT kompetencji tłumaczeniowych oraz realiami wykonywania zawodu. W ujęciu bardziej globalnym postuluje się rozdzielenie uprawnień na tłumaczenia pisemne i ustne oraz możliwość specjalizacji.

Słowa kluczowe: tłumacz przysięgły, egzamin pisemny, egzamin ustny, kompetencje tłumacza przysięgłego, realizm zawodowy, kryteria oceny
\end{abstract}

\section{Egzamin na tłumacza przysięgłego - rys historyczny}

Chociaż zawód tłumacza przysięgłego ma w Polsce bogatą, niemal stuletnią ${ }^{1}$ Utradycję, do czasu uchwalenia w 2004 roku ustawy o zawodzie tłumacza

${ }^{1}$ Rozporządzenie Ministra Sprawiedliwości w porozumieniu z Ministrem Skarbu z dnia 7 sierpnia 1920 r. w przedmiocie wynagrodzenia świadków, znawców i tłumaczów w postępowaniu karnym (Dz. U. Nr 75 poz. 515) oraz szerzej Kierzkowska (red.) (2011: 161). 
przysięgłego ${ }^{2}$ weryfikacja kompetencji kandydatów na tłumaczy przysięgłych nie była satysfakcjonująco uregulowana. Przez lata za dostateczne potwierdzenie znajomości języka obcego i umiejętności tłumaczenia uznawano - bezpodstawnie - dyplom ukończenia studiów wyższych na kierunku filologia. Jak powszechnie wiadomo, na studiach filologicznych zajęcia z przekładu prawnego i prawniczego należały i wciąż należą do rzadkości. Wprowadzony w 1968 roku egzamin ${ }^{3} \mathrm{z}$ umiejętności tłumaczenia tekstów ( $\mathrm{w}$ tym $\mathrm{z}$ dziedziny prawa) z języka obcego na język polski i z polskiego na język obcy dotyczył wyłącznie osób, które nie miały wykształcenia filologicznego. Nowelizacją rozporządzenia z roku $1987^{4}$ usunięto wymóg egzaminu, ograniczając dostęp do zawodu tłumacza wyłącznie do absolwentów studiów wyższych na kierunku filologia obca lub lingwistyka stosowana. W ten sposób ponownie bezpodstawnie $e^{5}$ uznano, iż dyplom ukończenia studiów filologicznych jest gwarancją umiejętności tłumaczenia. W rozporządzeniu zastrzeżono, że za zgodą Ministra Sprawiedliwości znajomość języka obcego i umiejętność tłumaczenia mogą być potwierdzone w inny sposób. W praktyce oznaczało to nierówne traktowanie kandydatów ponieważ tłumacze byli ustanawiani przy sądach wojewódzkich (później okręgowych), prezesi sądów ustalali dodatkowe wymogi, które istotnie różniły się w poszczególnych województwach. Co najważniejsze, ustawowe zapisy nie gwarantowały dostatecznej weryfikacji umiejętności tłumaczenia u kandydatów.

W tym kontekście wprowadzenie ustawą z 2004 roku wymogu zdania jednolitego zcentralizowanego egzaminu na tłumacza przysięgłego było ważną i potrzebną inicjatywą ustawodawcy, uchwaloną dzięki postulatom organizacji zawodowych zrzeszających tłumaczy.

\section{Weryfikacja kompetencji - etap 1: wykształcenie wyższe jako warunek sine qua non}

Ustawa otworzyła dostęp do zawodu tłumacza przysięgłego również dla osób, które nie mają wykształcenia filologicznego, nakładając na nie jednocześnie

\footnotetext{
2 Dz.U. z 2004 r., Nr 273 poz. 2702.

$3 \$ 2$ rozporządzenia Ministra Sprawiedliwości z dnia 19 sierpnia 1968 r. w sprawie tłumaczy przysięgłych (Dz. U. Nr 35 poz. 244).

${ }^{4} \$ 17.2$ rozporządzenia Ministra Sprawiedliwości z dnia 8 czerwca 1987 r. w sprawie biegłych sądowych i tłumaczy przysięgłych (Dz. U. Nr 18, poz. 112).

${ }^{5} \mathrm{Na}$ wielu filologiach nauka przekładu ogranicza się do 1-2 kursów, na ogół z tłumaczeń literackich lub prasowych, a w szczególności rzadko tłumaczenia ustne są obowiązkowym elementem programów filologicznych.
} 
wymóg ukończenia podyplomowych studiów tłumaczeniowych. Wymóg ten zniesiono zapisami ustawy z dnia 25 marca 2011 roku o ograniczaniu barier administracyjnych dla obywateli i przedsiębiorców ${ }^{6}$, pozostawiając jedynie warunek ukończenia studiów wyższych drugiego stopnia (tytuł magistra), który ma zostać zastąpiony wymogiem ukończenia jedynie studiów pierwszego stopnia?.

Zniesienie wymogu ukończenia studiów podyplomowych okazało się rozwiązaniem i dobrym, i złym. Należy podkreślić, że wymóg ten był niesprawiedliwy - ponownie implikował, iż absolwent studiów filologicznych jest należycie przygotowany do przystąpienia do egzaminu, a magister prawa nie jest. W rzeczywistości studia podyplomowe byłyby wskazane zarówno dla absolwentów prawa, którzy muszą poznać techniki tłumaczeniowe, jak i dla absolwentów filologii, którzy na studiach rzadko mają do czynienia z tekstami prawnymi i prawniczymi, a ponadto nie dysponują wiedzą z zakresu prawa polskiego i obcego. Co ważniejsze, wymóg ukończenia studiów podyplomowych stanowił barierę w dostępie do zawodu dla osób posługujących się rzadkimi językami, zwłaszcza jeżeli w Polsce dany język nie był nauczany na poziomie uniwersyteckim w ramach filologii. Studia podyplomowe z zakresu przekładu są w Polsce prowadzone przede wszystkim dla języków: angielskiego, niemieckiego, francuskiego, rosyjskiego, hiszpańskiego i włoskiego ${ }^{8}$, gdyż dla nich można zebrać odpowiednio liczebne grupy, które gwarantują samofinansowanie ${ }^{9}$ się studiów podyplomowych, a te nie są przecież finansowane z budżetu państwa. W konsekwencji dla rzadkich języków, a w zasadzie dla innych języków niż wymienione powyżej, nie ma możliwości odbycia studiów podyplomowych w Polsce. I tak uprawnienia tłumaczy przysięgłych obecnie, tj. na dzień 16 sierpnia 2017 roku, istnieją jedynie dla 51 języków ${ }^{10}$. Liczba ta jest naprawdę niewielka - dla porównania, według danych brytyjskiego ministerstwa Department for Education w samych angielskich szko-

${ }^{6}$ Dz.U. 2011 Nr 106 poz. 622.

7 Zob. wypowiedź Bolesława Cieślika, naczelnika Wydziału Tłumaczy Przysięgłych: http:// www.textem.com.pl/sites/textem.com.pl/files/ms-tlc-2014-sprawozdanie_0.pdf (dostęp: 2 października 2015 r.).

${ }^{8} \mathrm{Na}$ przykład Interdyscyplinarne Podyplomowe Studium Kształcenia Tłumaczy (IPSKT) na Uniwersytecie Warszawskim (https://www.ils.uw.edu.pl/80.html), którego celem jest kształcenie umiejętności w zakresie tłumaczenia prawniczego i sądowego oraz przygotowanie do wykonywania zawodu tłumacza przysięgłego.

9 Samofinansowanie studiów oznacza w praktyce nie tylko pokrycie kosztów z przychodów, ale również zapewnienie pokrycia odpisów ogólnouczelnianych, na ogół na poziomie 30-50\%.

${ }_{10}$ Stan ten nie zmienił się od co najmniej dwóch lat, kiedy powstała pierwsza wersja niniejszego artykułu. 
łach mówi się aż 311 różnymi językami (Espinoza 2015). Zasadnicza większość polskich tłumaczy przysięgłych reprezentuje języki, dla których istnieje w Polsce kształcenie filologiczne i studia podyplomowe - przykładowo, język niemiecki - 3834 tłumaczy, angielski - 2718, rosyjski - 1315, francuski - 1151, hiszpański - 315, włoski - 293 (przy czym najszybciej przyrasta liczba tłumaczy języka angielskiego). Są języki, dla których w ogóle nie ma ustanowionych tłumaczy przysięgłych, np. estoński, suahili, tajski, azerski, birmański, oraz języki, dla których ustanowiono zaledwie kilku tłumaczy, np.: amharski - 1 tłumacz, czarnogórski - 1, indonezyjski - 1, mongolski - 1, paszto 1, uzbecki - 1, dari -2 , hindi - 2, pendżabi - 2, albański - 4, koreański 4, ormiański - 4, gruziński - 5, łotewski - 5, fiński - 6. Warto podkreślić, iż języki popularne z dużą liczbą tłumaczy przysięgłych nie pokrywają się z zapotrzebowaniem polskiego wymiaru sprawiedliwości, który jest zobligowany dyrektywą 2010/64/UE z dnia 20 października 2010 roku w sprawie prawa do tłumaczenia ustnego i tłumaczenia pisemnego w postępowaniu karnym do zapewnienia tłumaczeń podejrzanym i oskarżonym. Pewną miarą takiego zapotrzebowania są statystyki policyjne dotyczące przestępczości cudzoziemców w Polsce. I tak w roku 2012 cudzoziemcy podejrzani o popełnienie przestępstw pochodzili najliczniej z następujących państw: Ukrainy, Białorusi, Litwy, Rumunii, Rosji, Niemiec, Bułgarii, Czech, Armenii czy Gruzji ${ }^{11}$. Inną miarą zapotrzebowania mogą być dane Straży Granicznej - w roku 2013 na polskich granicach zatrzymywano najczęściej obywateli Ukrainy, Rosji, Białorusi, Gruzji, Syrii, Wietnamu, Turcji i Armenii ${ }^{12}$. Oprócz niemieckiego i rosyjskiego pozostałe języki mają stosunkowo niewielu tłumaczy przysięgłych ${ }^{13}$.

Podsumowując, o ile pomysł obowiązkowych studiów podyplomowych był z pewnością pożyteczną inicjatywą, to zniesienie tego wymogu należy uznać za dobry krok - wyłącznie w kontekście: 1) potencjalnego otwarcia dostępu do egzaminu dla osób posługujących się rzadkimi językami oraz 2) nieuzasadnionego uprzywilejowanego traktowania absolwentów filologii poprzez zwolnienie ich z wymogu odbycia studiów podyplomowych. Jednakże powinno to być zrekompensowane bardziej precyzyjnym uregulowaniem kwestii dokształcania się przez tłumaczy przysięgłych (zob. postulat nr 8).

\footnotetext{
${ }^{11} \mathrm{http}: / /$ statystyka.policja.pl/st/wybrane-statystyki/przestepczosc-cudzozie/50867, Cudzoziemcy-przestepczosc.html (dostęp: 5 sierpnia 2015 r.).

12 http://www.strazgraniczna.pl/wps/portal/tresc?WCM_GLOBAL_CONTEXT=pl/ serwis-sg/polskie_formacje_graniczne/statystyki/ (dostęp: 5 sierpnia 2015 r.).

${ }^{13}$ Na przykład ukraiński - 208, białoruski - 26, bułgarski - 71, rumuński - 35, litewski 43, wietnamski - 20, arabski - 56, turecki - 19, mołdawski - 12, gruziński - 5 i ormiański - 4 .
} 


\section{Weryfikacja kwalifikacji - etap nr 2: egzamin na tłumacza przysięgtego}

Egzamin na tłumacza przysięgłego weryfikuje umiejętności tłumaczenia z języka polskiego na obcy i z języka obcego na polski. Chociaż wymóg tłumaczenia na język obcy byłby w krajach anglosaskich uznany za brak profesjonalizmu, w polskich warunkach rynkowych jest niezbędny.

Egzamin zdaje się przed Państwową Komisją Egzaminacyjną składającą się z 11 członków, którzy powinni mieć wysoki poziom wiedzy w zakresie języków obcych i technik tłumaczeniowych, w tym nauczycieli akademickich zatrudnionych na studiach na kierunku filologia i tłumaczy przysięgłych będących członkami organizacji zawodowych. Na wniosek Komisji możliwe jest powołanie konsultantów do przeprowadzenia egzaminu z określonego języka.

\section{Krytyczna ocena egzaminu - postulowane zmiany}

Po ponad 10 latach obowiązywania nowych przepisów zmieniających tryb przyznawania uprawnień tłumacza przysięgłego można pokusić się o ich ocenę i zaproponować rozwiązania optymalizujące, które umożliwią zbliżenie egzaminu do realiów wykonywania zawodu przez tłumaczy. Artykuł jest próbą krytycznej oceny części pisemnej egzaminu, zarówno od strony merytorycznej, jak i organizacyjnej.

Postulat nr 1: Rozdzielenie uprawnień dla tłumaczy ustnych i pisemnych oraz definiowanie specjalności dziedzinowych w bazie

Egzamin na tłumacza przysięgłego zdaje się w razie uzyskania pozytywnych ocen z części pisemnej i ustnej egzaminu, nie można zatem uzyskać uprawnień tylko w zakresie tłumaczeń pisemnych lub ustnych. Początkowo brano pod uwagę możliwość wprowadzenia odrębnych uprawnień, a co za tym idzie - możliwość zdania tylko jednej części egzaminu (zob. Dostatni 2005: 69). Jest to powszechnie praktykowane $\mathrm{w}$ wielu krajach, gdyż tłumaczenia ustne i pisemne wymagają odmiennych kompetencji. Nie każdy tłumacz pisemny będzie dobrym tłumaczem ustnym (np. z powodu braku umiejętności radzenia sobie ze stresem), a nie każdy tłumacz ustny będzie dobrym tłumaczem pisemnym (np. ze względu na skłonność do streszczania i parafrazowania). Argumentem przeciw rozdzieleniu egzaminu (choć mało zrozumiałym) miałoby być, jak pisze Dostatni, to, że „trudno wyobrazić sobie powoływanie 
przez organy państwa dwóch tłumaczy w postępowaniu prowadzonym na podstawie ustawy, gdy zachodzi potrzeba tłumaczenia zarówno ustnego, jak i pisemnego" (2005: 69).

Ważnym argumentem za jest ponadto niska zdawalność egzaminu ustnego - nie zdaje go ok. 50\% osób, które zdały egzamin pisemny. Warto podkreślić, iż tłumaczom specjalizującym się w językach rzadszych trudniej jest się przygotować i do egzaminu pisemnego, i do ustnego. Nie mają oni dostępu do studiów podyplomowych, kursów, zorganizowanych treningów przed egzaminem czy chociażby podręczników, słowników specjalistycznych i tekstów paralelnych.

W celu ułatwienia pracy sądom powinno się rozważyć możliwość definiowania w bazie specjalności dziedzinowych - nie każdy podejmie się tłumaczenia skomplikowanego tekstu medycznego, technicznego czy finansowego.

\section{Postulat nr 2: Jasne określenie zakresu dziedzinowego egzaminu}

$\mathrm{Na}$ egzaminie do przetłumaczenia są 4 teksty - 2 na język polski i 2 z języka polskiego, w tym jeden tekst $\mathrm{w}$ każdej grupie musi być pismem sądowym, urzędowym lub tekstem prawniczym ${ }^{14}$. Rozporządzenie zostawiło zbyt dużą dowolność komisji egzaminacyjnej w doborze drugiego tekstu - w praktyce może to być np. tekst medyczny czy techniczny. Przy rosnącej specjalizacji tłumaczeń (zob. Biel 2011: 163) pozostawienie możliwości tak szerokiego spektrum dziedzinowego jest nieprofesjonalne i utrudnia racjonalne przygotowanie się do egzaminu. Nie można przecież wymagać od kandydatów, aby byli specjalistami we wszystkich dziedzinach. Jest to sprzeczne $\mathrm{z}$ realiami rynkowymi - tłumacz specjalizujący się w więcej niż 2-3 dziedzinach jest na rynku niewiarygodny. Również Kodeks tłumacza przysięgłego za jedną z przesłanek odmowy tłumaczenia przewiduje brak wystarczającej wiedzy fachowej lub nieznajomość terminologii specjalistycznej w danej dziedzinie (\$4, Kierzkowska (red.) 2011).

Kandydaci powinni otrzymać jasną informację o zakresie dziedzinowym testów egzaminacyjnych - najlepiej, aby wszystkie teksty były ograniczone do pism sądowych, urzędowych lub tekstów prawnych i prawniczych, gdyż takimi najczęściej zajmują się tłumacze przysięgli.

14 Rozporządzenie Ministra Sprawiedliwości z dnia 24 stycznia 2005 r. w sprawie szczegółowego sposobu przeprowadzenia egzaminu na tłumacza przysięgłego (Dz.U. z 2005 r., Nr 15 poz. 129) (dostęp: 5 sierpnia 2015 r.). 
Postulat nr 3: Wprowadzenie na egzaminie pisemnym komputerów z dostępem do Internetu

Według informacji zamieszczonych na stronie Ministerstwa Sprawiedliwości ${ }^{15}$ na egzaminie nie można korzystać $z$ własnego komputera. Jak donosił w 2014 roku Adam Szafrański ${ }^{16}$, przewodniczący Państwowej Komisji Egzaminacyjnej na konferencji Translation and Localisation Conference, Komisja zamierzała wprowadzić komputery „na egzaminach z języków popularnych” i w związku z tym wystąpiła do Ministerstwa Sprawiedliwości z prośbą o zakup tych urządzeń. W przeciągu trzech lat od tej deklaracji komputerów nie udało się zakupić. Kolejnym problemem są plany udostępnienia komputerów wyłącznie jako edytora tekstu bez funkcji autokorekty i bez dostępu do Internetu. Doktor Szafrański zauważa, że na egzaminach prawniczych kandydaci mogą pracować na własnych komputerach z blokadą dostępu do oprogramowania, jednak jego zdaniem „taka metoda nie sprawdzi się w przypadku egzaminu na tłumacza przysięgłego”. Komisja uważa, że „egzamin ma sprawdzać nie umiejętność korzystania z programów komputerowych, tylko z własnej wiedzy, ewentualnie wiedzy słownikowej”. Jednocześnie Komisja planuje zostawić możliwość ręcznego pisania dla osób, które „nie lubią komputerów”17 (sic!). Jest to w oczywisty sposób sprzeczne $\mathrm{z}$ realiami rynkowymi - trudno sobie wyobrazić w obecnych czasach tłumacza tekstów specjalistycznych, który tłumaczenie sporządza odręcznie, nie korzystając z edytora tekstów i bogatego zasobu wiedzy w Internecie.

Postulat nr 4: Dopuszczenie na egzaminie pisemnym możliwości korzystania $z$ podstawowych pomocy warsztatowych: słowników, leksykonów, encyklopedii, tekstów ustaw i ich tłumaczeń

Na egzaminie pisemnym kandydaci mogą korzystać wyłącznie z przyniesionych przez siebie słowników papierowych, w tym również ze słowniczków własnego autorstwa (pod warunkiem dopuszczenia ich przez komisję egzaminacyjną). Zakazane są natomiast teksty ustaw polskich i obcojęzycznych, tłumaczenia ustaw, encyklopedie (w tym encyklopedie prawa), leksykony -pytania/

${ }^{15}$ http://bip.ms.gov.pl/pl/rejestry-i-ewidencje/tlumacze-przysiegli/najczesciej-zadawane-

16 Transkrypcja wypowiedzi: Textem http://www.textem.com.pl/sites/textem.com.pl/files/ ms-tlc-2014-sprawozdanie_0.pdf (dostęp: 2 października 2015 r.).

17 Op. cyt. Textem. 
i podręczniki ${ }^{18}$. Termin „słownik” jest rozumiany bardzo wąsko - wykluczono słowniczki własne, zawierające tłumaczenia całych zdań lub fragmentów ustaw oraz opublikowane słowniki, które obejmują definicje terminów, np. Polsko-angielski słownik terminów prawnych PolTerm $z$ definicjami autorstwa Tomasza Borkowskiego (Translegis, 2011), gdyż zostały one uznane za leksykony (zob. Cieślik ${ }^{19}$ 2014: 97).

Tak restrykcyjne podejście jest zupełnie niezrozumiałe i istotnie odbiega od tego, jak w rzeczywistości pracują tłumacze pisemni (przysięgli). Jedną z podstawowych kompetencji tłumaczeniowych w znanym modelu kompetencji EMT (European Master's in Translation), opracowanym przez grupe ekspertów powołaną przez Dyrekcję Generalną ds. Tłumaczeń Komisji Europejskiej (Gambier (red.) 2009) i dostosowanym w ramach projektu Qualetra przez prof. Federicę Scarpę i Daniele’a Orlando do tłumaczy prawniczych (2017), jest umiejętność wyszukiwania informacji (ang. information mining), która obejmuje prawidłową identyfikację potrzeb informacyjnych, umiejętność wyszukiwania i przetwarzania informacji (dokumentowych, terminologicznych czy frazeologicznych) na potrzeby danego zadania, wypracowanie kryteriów oceny zasobów internetowych i na innych nośnikach (krytyczna ocena wiarygodności źródeł) oraz umiejętność skutecznego korzystania z narzędzi i wyszukiwarek (zob. Gambier (red.) 2009). W mojej ocenie jest to jeden $\mathrm{z}$ najważniejszych elementów kompetencji tłumaczeniowej, który gwarantuje, że tłumacz będzie sobie sprawnie radził z różnego typu tekstami i nowymi sytuacjami. Kompetencje w zakresie wyszukiwania informacji przewiduje również Kodeks tłumacza przysięgłego: „Tłumacz przysięgły ma obowiązek wykorzystania wszelkich dostępnych mu pomocy warsztatowych: słowników, encyklopedii, podręczników, baz terminologicznych i norm oraz innych źródeł wiedzy oraz korzystania z konsultacji znawcy przedmiotu $\mathrm{w}$ celu zapewnienia najwyższej jakości tłumaczenia" (\$ 8, Kierzkowska (red.) 2011: 12). Tłumacz musi wiedzieć, jak w gąszczu informacji sprawnie i prawidłowo wyszukać potrzebne dane, jak ocenić ekwiwalent, opierając się na wiarygodnych źródłach, tj. aktach prawnych, oficjalnych bazach terminologicznych, stronach instytucji rządowych, tekstach paralelnych. Należy podkreślić, że w tłumaczeniu prawnym i prawniczym słownik nie jest wiarygodnym źródłem informacji (szczególnie $\mathrm{z}$ uwagi na niską jakość słowników prawniczych, chociażby w parze angielsko-polskiej).

18 Zob. również $\$ 3$ rozporządzenia Ministra Sprawiedliwości z dnia 24 stycznia z $2005 \mathrm{r}$. w sprawie szczegółowego sposobu przeprowadzenia egzaminu na tłumacza przysięgłego.

${ }^{19}$ Cieślik słusznie opowiada się za rozszerzeniem definicji słownika na leksykony (2014: 97). 
W praktyce słownik jest pierwszym etapem wyszukiwania ekwiwalentu, który weryfikuje się w aktach prawnych krajowych i obcych, ich tłumaczeniach, a przede wszystkim w Internecie, pod kątem uzusu. Aby wykonać tłumaczenie o jakości rynkowej, tłumacz potrzebuje dostępu do wiedzy encyklopedycznej, a nie słownikowej. Wyeliminowanie tych integralnych części prawidłowego procesu wyszukiwania ekwiwalentu jest chybione, anachroniczne i bezzasadne. Warto zauważyć, iż przetłumaczenie w ciągu godziny trudnego tekstu egzaminacyjnego o objętości średnio 1800 znaków pozostawia niewiele czasu na przeszukiwanie materiałów, i aby zdać egzamin, kandydat musi w znacznym stopniu polegać na zinternalizowanej wiedzy oraz terminologii. Z wypowiedzi członków komisji i przedstawicieli Ministerstwa można wnioskować, że panuje błędne przekonanie, iż wykluczenie tego rodzaju pomocy sprawdza „rzeczywiste” umiejętności kandydatów (zob. np. wypowiedź pana Bolesława Cieślika, który argumentując za rozszerzeniem definicji słownika, stwierdza, że „wykluczenie innego rodzaju pomocy naukowych, jak wzory pism, i tak będzie wystarczające, aby mieć pewność, że egzamin sprawdza rzeczywiste umiejętności kandydata" (2014: 97)). Oczywiście pozostaje problem zapewnienia samodzielności pisania egzaminu, ale można go rozwiązać poprzez specjalne programy monitorujące dostęp do stron.

Powyższe wnioski nasuwają się również po lekturze skądinąd przydatnej książki pt. Egzamin na tłumacza przysięgłego w praktyce. Język angielski. Analiza jezykowa (2013) autorstwa członka komisji egzaminacyjnej, prof. Kuźniaka, która omawia częste błędy na egzaminie na tłumacza przysięgłego. Trudno oprzeć się wrażeniu, że części błędów można by uniknąć, gdyby kandydaci mieli dostęp do źródeł internetowych. Przykładowo, aby prawidłowo przetłumaczyć nazwę Naczelnego Sądu Administracyjnego, trzeba wejść na jego stronę internetową w języku angielskim i sprawdzić, jaką nazwą Sąd tam się posługuje. Kolejną kwestią jest dobór tekstów egzaminacyjnych w świetle braku dostępu do Internetu. W książce widnieją przykłady autentycznych tekstów egzaminacyjnych pochodzących z różnych jurysdykcji - Wielkiej Brytanii, USA, Kanady i Australii. Nie powinny one sprawić problemu tłumaczowi mającemu dostęp do Internetu, ale z dostępem jedynie do słowników - w których co do zasady nie oznacza się pochodzenia terminu - trudno jest uzyskać profesjonalną, rynkową jakość tłumaczenia. Ponadto część tekstów egzaminacyjnych dotyczy tematyki unijnej - w książce Kuźniaka (2013) są to teksty o nazwach: 1) uznawanie wykształcenia w UE; 2) wniosek o wydanie orzeczenia prejudycjalnego czy 3) Europejski Trybunał Praw Człowieka. Jednym z podstawowych kryteriów oceny jakości tłumaczenia unijnego jest jego zgodność z bazą terminologiczną IATE i urzędowymi tłumaczenia- 
mi powiązanych dokumentów w bazie aktów prawnych EUR-Lex (zob. Biel 2014). Bez dostępu do Internetu teksty o tematyce unijnej na egzaminie są nieporozumieniem.

\section{Postulat nr 5: Umożliwienie dostępu do słowników podczas egzaminu ustnego}

Rozporządzenie dopuszcza możliwość korzystania ze słowników wyłącznie podczas egzaminu pisemnego. Należy ją rozszerzyć na tłumaczenia ustne zgodnie z realiami wykonywania zawodu. Warto zauważyć, iż Kodeks tłumacza przysięgłego dopuszcza możliwość korzystania przez tłumacza przysięgłego ze słownika podczas tłumaczenia ustnego (\$69, Kierzkowska (red.) 2011:27).

Postulat nr 6: Modyfikacja kryteriów oceny - wprowadzenie błędu krytycznego, zwiększenie wagi kryterium zgodności treści i zmiana klasyfikacji błędu stylistycznego

Biorąc pod uwagę specyfikę tłumaczeń poświadczonych, w rozporządzeniu przewidziano stanowczo zbyt niską wagę (10 pkt) dla kryterium zgodności treści przekazanej $\mathrm{w}$ tłumaczeniu $\mathrm{z}$ treścią oryginału. Kryterium ma identyczną wagę jak poprawność językowa czy zastosowanie rejestru funkcjonalnego, choć w praktyce nawet jeden błąd w przekazie informacji, np. zgubienie „not”, cyfry 0 w kwocie wynagrodzenia czy zniekształcenie nazwiska, może całkowicie zdyskwalifikować tłumaczenie. Niektóre elementy tekstu wiążą się $\mathrm{z}$ wysokim ryzykiem (np. data urodzenia w odpisie aktu urodzenia), inne zaś z niskim, przy czym nie zawsze jest ono tożsame z poziomem trudności (szerzej: Pym 2015: 72). W brytyjskich testach dla kandydatów na publicznych tłumaczy ustnych Public Service Interpreters istnieje kategoria błędu krytycznego (ang. fatal error) ${ }^{20}$ - poważnego błędu skutkującego niezaliczeniem całego testu (zob. szerzej: Biel 2012), który również powinien być wprowadzony do polskiego egzaminu. Nie ma oficjalnych informacji o zasadach oceniania testów egzaminacyjnych, jednak w książce prof. Kuźniaka, członka komisji egzaminacyjnej, można znaleźć niepokojące stwierdzenie: „Jeśli podczas egzaminu kandydat opuści w translacie istotne dla danego tekstu fragmenty, to wówczas przyjęło się traktować takie postępowanie w kategoriach błędu zgodnościowego w proporcji: jeden opuszczony leksem - minus jeden punkt” (2013: 10). Czy zatem opuszczenie jednego leksemu „not” w zdaniu

${ }^{20}$ https://www.ciol.org.uk/images/Qualifications/DPSI/DPSIFatalErrors.pdf (dostęp: 5 sierpnia 2015 r.). 
„I plead not guilty” (nie przyznaję się do zarzucanego czynu) w protokole przesłuchania podejrzanego, które powoduje, że cały dokument ma odwrotny wydźwięk i stawia podejrzanego w innej sytuacji, dyskwalifikując tym samym całe tłumaczenie, powinno otrzymać zaledwie jeden ujemny punkt (na 50)? Ważne zatem wydaje się zwiększenie wagi kryterium zgodności tekstu oraz wprowadzenie błędu krytycznego.

Kategorią o zawyżonej wadze (10 pkt) jest $\mathrm{z}$ kolei niejasne kryterium błędu stylistycznego - zastosowanie rejestru (stylu funkcjonalnego) języka właściwego dla danego rodzaju tekstu - wydzielone z kategorii poprawności gramatycznej, ortograficznej i leksykalnej (również 10 pkt). Łącznie za aspekty językowe można uzyskać 20 pkt, natomiast za zgodność treści jedynie 10 pkt. Na nieostrość kategorii stylistycznej zwrócił uwagę prof. Artur Kubacki, słusznie postulując uwzględnienie jej w błędach językowych (2012: 233). Jak podkreśla Kubacki na podstawie własnych doświadczeń egzaminacyjnych, jest to najwyżej oceniane kryterium, „[r]zadko bowiem dochodzi do naruszenia stylu funkcjonalnego języka, np. zastosowania wyrażenia właściwego dla języka potocznego w piśmie urzędowym" (2012: 234). O tym, że jest to kategoria problematyczna, można się przekonać, przeglądając przykłady błędów stylistycznych w książce Kuźniaka (2013), który do tej grupy zalicza takie błędy, jak: przetłumaczenie firmy spółki, nieprzetłumaczenie nazwy instytucji czy stopnia policjanta, nierozwinięcie skrótu, które to błędy ewidentnie należą do kategorii przekazu informacji (zgodność treści).

\section{Postulat nr 7: Poprawa polityki informacyjnej Wydziału Tłumaczy Przy- sieglych}

Od czasu napisania przeze mnie krytycznej recenzji książek z testami egzaminacyjnymi (Biel 2012), w której zarzuciłam Wydziałowi Tłumaczy Przysięgłych w Ministerstwie Sprawiedliwości fatalną politykę informacyjną (a w zasadzie jej brak), z satysfakcją odnotowuję pierwsze zmiany w tym zakresie. Ministerstwo rozbudowało stronę dla kandydatów, wprowadzając przydatną sekcję Najczęściej Zadawane Pytania. W 2013 roku zapowiedziano plany publikacji testów egzaminacyjnych, choć „w tej chwili nie jest to priorytet” ${ }^{21}$. Plany zrealizowano dopiero pod koniec 2016 r., publikując kilka przykładowych testów dla najpopularniejszych języków: angielski, francuski, niemiecki

${ }^{21}$ B. Cieślik, http://www.textem.com.pl/sites/textem.com.pl/files/ms-tlc-2014-sprawozdanie_0.pdf (dostęp: 5 sierpnia 2015 r.). 
i rosyjski ${ }^{22}$. Przykładowe testy egzaminacyjne są dostępne również odpłatnie (do niedawna wyłącznie w tej formie), np. Rybińska (red.) (2011) oraz Cieślik $\mathrm{i}$ in. (2010). Wzorem brytyjskiej organizacji Chartered Institute of Linguists (CIOL) Ministerstwo powinno również zamieścić nieodpłatne omówienie typowych błędów dla poszczególnych par językowych i inne materiały przygotowawcze, zamiast polegać na komercyjnych publikacjach członków komisji egzaminacyjnej.

\section{Postulat nr 8: Doprecyzowanie wymogu kształcenia ustawicznego tłuma- czy przysięgłych}

Konsekwencją zniesienia wymogu studiów podyplomowych dla absolwentów studiów niefilologicznych powinno być doprecyzowanie wymogu doskonalenia kwalifikacji zawodowych przez tłumaczy przysięgłych (art. 14 pkt 3 ustawy). Jest to o tyle istotne, że ok. 10000 tłumaczy uzyskało uprawnienia na podstawie wcześniejszych przepisów, a więc w zasadzie bez egzaminu. Wymóg ustawicznego kształcenia widnieje również w Kodeksie tłumacza przysięgłego: „Tłumacz przysięgły jest zobowiązany do stałego doskonalenia swoich kwalifikacji translatorskich, językowych i merytorycznych, w tym również podstawowej wiedzy w zakresie krajowego i międzynarodowego obrotu prawnego tłumaczonych dokumentów, zgodnie z obowiązkiem określonym w ustawie o zawodzie tłumacza przysięgłego" (\$7, Kierzkowska (red.) 2011: 46).

Przepis art. 14. pkt 3 jest uważany za nieostry i kontrowersyjny, ponieważ jest to „norma pozbawiona sankcji” (Dostatni 2005: 93). Kierzkowska sugeruje, że dokształcanie się może mieć pozytywny wpływ w przypadku oceny tłumacza przez Komisję Odpowiedzialności Zawodowej (2011: 46). Aby wymóg kształcenia ustawicznego był skuteczny, należy go doprecyzować i wprowadzić sankcje za jego nieprzestrzeganie, np. konieczność uzyskania X punktów za szkolenia czy udział w konferencjach w okresie 5 lat pod rygorem wykreślenia z rejestru (podobne rozwiązania istnieją m.in. w Holandii).

\section{Literatura}

Biel, Ł., 2011, „Professional Realism in the Legal Translation Classroom: Translation Competence and Translator Competence”, Meta. Translators'

${ }^{22}$ https://bip.ms.gov.pl/pl/rejestry-i-ewidencje/tlumacze-przysiegli/przykladowe-teksty-egzaminacyjne/ (dostęp: 17 sierpnia 2017 r.). 
Journal 56 (1), s. 162-178.

Biel, Ł., 2012, „Egzamin na tłumacza przysięgłego - zbiory testów egzaminacyjnych", Comparative Legilinguistics. International Journal for Legal Communication 9/2012, s. 103-108.

Biel, Ł., 2014, Lost in the Eurofog: The Textual Fit of Translated Law, Frankfurt am Main.

Cieślik, B., 2014, Materiały pomocnicze na egzaminie na tłumacza przysięłego, „Rocznik Przekładoznawczy. Studia nad teorią, praktyką i dydaktyką przekładu”, M. Krajewska, L. Zieliński (red.), nr 9, s. 89-99.

Cieślik, B., L. Laska, M. Rojewski (red.), 2010, Egzamin na tłumacza przysięgłego. Komentarz, teksty egzaminacyjne, dokumenty, Warszawa.

Dostatni, G., 2005, Komentarz do ustawy o zawodzie tłumacza przysiegłego, Warszawa.

Espinoza, J., 2015, „More than 300 different languages spoken in British schools, report says", The Telegraph, 24.07.2015, http://www.telegraph. co.uk/education/educationnews/11761250/More-than-300-differentlanguages-spoken-in-British-schools-report-says.html (dostęp: 31 lipca 2015 r.).

Gambier, Y. (red.), 2009, „Competences for professional translators, experts in multilingual and multimedia communication", http://ec.europa.eu/ dgs/translation/programmes/emt/key_documents/emt_competences_ translators_en.pdf (dostęp: 30 lipca 2015 r.).

Kierzkowska, D. (red.), 2011, Kodeks tłumacza przysięłego z komentarzem, Warszawa.

Kubacki, A. D., 2012, Tłumaczenie poświadczone. Status, kształcenie, warsztat i odpowiedzialność tłumacza przysięgłego, Warszawa.

Kuźniak, M., 2013, Egzamin na tłumacza przysięgłego w praktyce. Język angielski. Analiza językowa, Warszawa.

Pym, A., 2015, „Translating as risk management”, Journal of Pragmatics 85, s. $67-80$.

Rybińska, Z. (red.), 2011, Teksty egzaminacyjne dla kandydatów na tłumacza przysięgłego, Warszawa.

Scarpa, F., Orlando, D., 2017, „What it takes to do it right: an integrative EMT-based model for legal translation competence", Journal of Specialised Translation 27, s. 21-42. 
ŁUCJA BIEL

The sworn translator examination versus the reality of professional practice: a critical voice in connection with the verification of sworn translator candidates' competences

Summary

The paper attempts to critically evaluate the sworn translator examination in the light of the reality of professional practice. The analysis will cover the following components: assessment criteria, including the relatively low rating of the information transfer criterion and lack of the critical (fatal) error criterion, prohibition to use reference materials (encyclopaedic dictionaries, legislation) and a limited possibility to use dictionaries, lack of access to the Internet, and the need to hand-write the examination. These elements will be correlated with the EMT model of translation competencies and the realities of professional practice. The paper proposes eight postulates which can improve the translation part of the sworn translator examination by adjusting it to a greater degree to skills and competences required of sworn translators on the job. Finally, it is suggested to separate translation from interpreting certifications and to introduce specialisations.

Keywords: sworn translator, translation examination, interpreting examination, competences of sworn translators, professional realism, marking criteria 